\title{
Os arquivos do luto e as lições patéticas: uma educação sentimental em Anne Carson
}

Resumo: $O$ artigo pretende demonstrar a prática da tradução em Anne Carson como uma ação investigativa nos "arquivos do luto" [archives of grief]. Explica como essa pesquisa resulta não apenas em produtos (os textos traduzidos), como também em um conjunto de "lições patéticas", que ensinam algo sobre o pathos e reinformam o ethos. $\mathrm{O}$ artigo também inclui uma exposição sobre a releitura que Carson faz da teoria da tradução de Walter Benjamin, com a qual concebe a tradução como uma escuta da ruína do original. $O$ objeto de análise inclui ensaios de Carson e algumas de suas traduções de tragédias clássicas, em especial os textos de Grief Lessons, que contêm peças de Eurípedes, bem como Antigonick, a tradução de Carson para a Antígona de Sófocles.

Palavras-chave: Anne Carson, Walter Benjamin, tradução, luto, arquivo

Abstract: This article's goal is to demonstrate Anne Carson's practice of translation as a research activity in the "archives of grief". It explains how this research results not only in products (the translated texts), but also in a set of "pathetic lessons", teaching something about the pathos and reinforming the ethos. The article also includes an exposition on Carson's rereading of Walter Benjamin's theory of the translation, with which she conceives translation as a hearing of the original's ruin. The object of analysis includes some of Carson's essays and some of her translations of classical tragedies, the ones in Grief Lessons, with Euripides plays, as well as Antigonick, Carson's translation of Sophocles' Antigone.

Keywords: Anne Carson, Walter Benjamin, translation, grief, archive 
O que sobrevive nos arquivos faz isso por acaso. O desaparecimento é a regra. Susan Buck-Morss

By suffering we learn. O coro em Agamemnon, de Ésquilo, traduzido por Anne Carson

A poeta e classicista Anne Carson é uma tradutora incomum. Nas duas últimas décadas, publicou versões de textos gregos para o inglês bastante heterodoxas. Para se ter uma ideia dessa heterodoxia, na tradução que realizou das Bacantes de Eurípides, e que publicou em 2015, a fala de abertura de Dionísio é um comentário sobre a própria tradução. Esse comentário se refere à dificuldade de se nomear a própria natureza desse ente em inglês: "não [sou] exatamente deus, fantasma, espírito, anjo, princípio ou elemento - / Não há termo para isso em inglês. / Em grego se diz daimon - / podemos usar esse termo?"1 (Carson / Eurípedes 2015: 16)

Já na sua tradução da Antígona de Sófocles, publicada pela primeira vez em 2012, a heroína da peça, junto à irmã, fora do palácio, debate uma frase de Hegel parodiada por Beckett (Carson / Sófocles 2015: 9). Carson assina ambos os trabalhos não como criações de sua autoria, mas sim de seus respectivos tragediógrafos, ainda que nem Eurípedes tenha conhecido o inglês com que Carson trabalha, nem Sófocles tenha tido notícia de Hegel e Beckett, que nasceriam no futuro. Carson assina como tradutora.

Também o volume intitulado Grief Lessons, publicado em 2006, tem a sua cota de heterodoxia. Nele, além de quatro tragédias de Eurípedes traduzidas por Carson, a tradutora nos dá a ler um epílogo em que o próprio tragediógrafo explicaria "Por que escrevi duas peças sobre Fedra" - sim, o texto é "assinado" pelo dramaturgo, embora tenha sido escrito por Carson (Carson 2006f).

Essas heterodoxias parecem incluir comentários sobre a vida afetiva e pulsional: nas Bacantes (publicadas como Bakkhai na tradução de Carson), o comentário sobre Dionísio como um daimon precede uma peça que coloca o deus como o pivô de um retorno do recalcado, isto é, configura o preâmbulo de uma discussão sobre o desejo. Na Antígona (nomeada pela tradutora como Antigonick), as falas da heroína que retomam Hegel debatem algumas das considerações do filósofo moderno alemão sobre a relação entre consciência, culpa, lei e, principalmente, desejo que atravessa a tragédia. E o texto "de Eurípedes", sobre as duas versões de Fedra, pode ser sintetizado como uma discussão não apenas sobre a heroína, como também sobre a arte de cobrir o desejo de peles ou camadas de desejo.

Acresce-se a isso o fato de que esses textos traduzidos são tragédias (Carson não parece muito interessada em comédias). Acarretam, portanto, uma boa dose de pathos: 
sofrimento, paixão. São arquivos do luto - essa denominação vem de Carson. Este artigo pretende, por um lado, esclarecer o que são esses arquivos do luto - e por que motivo podem ser chamados de arquivos. Por outro lado, o artigo pretende também articular o que esses arquivos podem nos ensinar - é Carson quem denomina uma de suas obras, que remexem nesse arquivo, como Lições do Luto [Grief Lessons]. ${ }^{2}$

O que media o arquivo e a lição, em Carson, é a prática da tradução. E somente num paradigma que admita uma autonomia da tradução é possível tomá-la como uma determinada ação que tem função própria nesses arquivos. É deste ponto de mediação que partiremos.

\section{Tradução e tarefa, forma e autonomia}

Essa autonomia da tradução, a forma específica como ela é concebida, não começa com Anne Carson. De fato, a tradutora se insere numa determinada tradição e participa da herança da teoria da tradução de Walter Benjamin, na qual vemos a defesa explícita da tradução como uma forma (Benjamin 2011: 102). ${ }^{3}$

Essa teoria aparece pela primeira vez na década de 1920, num ensaio do filósofo alemão que introduzia as traduções que fizera de Charles Baudelaire. Nele, Benjamin repensa a "tarefa [Aufgabe] do tradutor", ${ }^{4}$ vislumbrando para o produto desse trabalhador das letras uma autonomia decisiva com relação ao original em outra língua. Benjamin se contrapõe às teorias tradicionais que situam a tradução em um lugar de subordinação em relação ao texto original. Essa subordinação recebe o nome de "rebaixamento" em um livro de Susana Kampff Lages sobre Walter Benjamin: Tradução e melancolia: "a história da tradução e da imagem do tradutor que escritores, filósofos e os próprios tradutores e teóricos da tradução forjaram ao longo dos séculos pode ser descrita como uma história de rebaixamentos", diz a autora, e paralelamente, pode ser nomeada como uma tradição de recorrente desvalorização do tradutor (Lages 2007: 65). Para Lages, que estabelece em sua obra uma breve história das teorias da tradução, a exigência de "fidelidade" ou "humildade" ocasionam, no limite, um "anulamento total da personalidade do tradutor", que deve se manter oculto, preferencialmente invisível, e baixar as suas expectativas com relação a uma equivalência entre a tradução e o texto traduzido, em favor de uma meta modesta de "aproximação" com relação ao original (idem: 70).

É justamente o conceito de "tarefa" que oferece outra perspectiva para a tradução. Em Benjamin, tal conceito pressupõe autonomia ao gênero literário da tradução, liberando-o tanto de seu papel de subordinação tradicional, quanto de sua necessidade de autoafirmação por equivalência ou oposição ao texto traduzido. A tradução não aparece como um gênero útil, que transporta o original, rebaixado, para um novo contexto linguístico. Ela faz alguma coisa ela própria. A palavra alemã Aufgabe, do título, já o indica, mediante seu amplo espectro de significação. Quanto a isso, a nota de Jeanne Marie Gagnebin à tradução brasileira diz o seguinte: 


\begin{abstract}
O verbo aufgeben, do qual provém o substantivo Aufgabe, significa "entregar", no duplo sentido do termo: "dar" (geben) algo a alguém para que cuide disso (por exemplo, entregar uma carta ao correio), mas também dar algo a alguém, abrindo mão da posse do objeto (por exemplo, entregar uma cidade ao inimigo). A segunda acepção é mais forte no uso intransitivo do verbo: ich gebe auf - "renuncio", "desisto", "me entrego". Essa ambivalência está presente no substantivo Aufgabe, entendido como "proposta", "tarefa", "problema a ser resolvido", mas no qual ressoam também as ideias de "renúncia" e "desistência". (Gagnebin in Benjamin 2011: 101)
\end{abstract}

A tarefa e a renúncia do tradutor diante do original é o que rompe o fio de fidelidade e subordinação que sustenta a relação de endereçamento da tradução ao texto traduzido. Segundo Haroldo de Campos, trata-se de uma autonomia tamanha que ameaça, no limite, o próprio original. Em "Para além do princípio da saudade", o poeta e crítico afirma existir em Benjamin o projeto de uma destruição demoníaca do original em favor da tradução criadora. Em suas palavras:

[...] a ênfase benjaminiana na primazia arquetípica das "monstruosas" traduções hölderlinianas permite-nos dar um passo mais adiante e ultimar a sua teoria, revertendo a função angélica do tradutor numa empresa luciferina[...] Em vez de render-se ao interdito do silêncio, o tradutor-usurpador passa, por seu turno, a ameaçar o original com a ruína da origem. Esta, como eu a chamo, a última hýbris do tradutor luciferino: transformar, por um átimo, o original na tradução de sua tradução. Reencenar a origem e a originalidade como plagiotropia [...] (Campos 2015: 56)

A prática da tradução evidenciaria a própria cena da origem como uma empresa de tradução ela mesma, desestabilizando, por fim, a ideia de "original". O texto traduzido diferiria do original, então, à semelhança da distância do próprio original daquilo que arrisca dizer. A tradução seria uma espécie de novo lugar de fala de onde se pode arriscar aquilo que se tinha a dizer. 0 tradutor não transporta um texto, mas desdobra forças, que se encontram (ou se encontravam na "cena de origem", segundo o comentário de Campos) no original, em novas formas. A tarefa do tradutor não seria transpor conteúdos entre línguas, mas fabricar uma analogia que mantém um "eco" daquilo que "fala" no original, ao mesmo tempo em que sustenta, em seus materiais, um grau de diferença.

É isso que Carson "ouve" no texto de Benjamin. Não apenas ouve, mas confere a essa hipótese de autonomia da tradução algo novo. Se em Benjamin ela é uma forma, em Carson ela aparece como uma performance. A tradução não apenas resulta num determinado texto que se descola de sua origem e ganha vida própria - a sua prática mesma faz alguma coisa. O que é que essa tradução faz?

Algumas hipóteses foram aventadas por outros pesquisadores, com especial intensidade depois que esse gesto performativo de Carson se radicalizou e chamou a atenção com Antigonick, no início da década passada. Uma delas é a de que a sua tradução apare- 
ce como estratégia intermídia de reescritura do original (Gonçalves / Nascimento 2019: 82). Dessa maneira, a transposição de conteúdos entre diferentes mídias, aliadas a uma preocupação feminista, conferiria sempre novos significados ao texto traduzido. Outra hipótese é a de que suas traduções funcionariam como ensaios sobre o texto original. Antigonick, peça de Carson, seria uma leitura ensaística sobre a Antígona de Sófocles (Moreira 2015: 120). Isso explicaria por que a tradutora inclui alusões no texto traduzido à história de sua recepção, principalmente as teses de Hegel sobre a tragédia. Uma terceira chave de leitura se refere ao gesto de Carson como o de "transposição de um tempo a outro, de uma cultura a outra, de uma compreensão de mundo a outra", e não apenas dos conteúdos do texto traduzido (Moreira 2019: 251). Há também a tese de que assistimos nessa prática a uma reprodução do jogo de presenças e ausências do próprio teatro, como se sua tradução tentasse incorporar na forma o que é fantasmático no teatro e o que assombra essas peças (Silverblank 2014: 347). Existe, por fim, a hipótese de que sua tradução se encontra numa encruzilhada entre performance e filosofia, continuando o projeto de Benjamin em A tarefa do tradutor (Hjorth 2014).

A esse repertório de hipóteses, gostaria de acrescentar outra chave de interpretação, com a qual este artigo busca contribuir. Sustento que a performance da tradução de Anne Carson se configura como uma atividade de escuta não apenas do sentido como também do sem sentido do original - leia-se a origem, a arkhé, o arcaico, o arquivo. A mediação que procuramos, entre luto e lição, se dá através dessa escuta. Esse sem sentido do original aparece como uma série de ruídos que são reencenados na tradução, de modo a nos reenviar a sua estranheza, retirando cada sofrimento em particular do acúmulo de ruínas que constitui os arquivos do luto. Por fim, proponho que essa performance visa algo como uma educação sentimental.

\section{Escutar a barbárie, escutar a ruína}

Anne Carson não é meramente uma continuadora da teoria da tradução de Benjamin, pelo menos não em sentido estrito. A sua leitura dessa teoria toma rumos não previstos pelo filósofo. Antes de qualificar, portanto, o que fazem as suas traduções com os arquivos do luto, e antes de tipificar a educação sentimental que se anuncia aí, vamos relembrar dois textos em que Carson alude ao ensaio sobre "A tarefa do tradutor" de Benjamin.

O primeiro deles é uma introdução às suas traduções de Safo no volume If not, winter. O texto de Benjamin é citado pela tradutora de modo a justificar seus motivos para, ao verter os poemas de Safo para o inglês, dispor as palavras com um espaçamento que não encontramos nas transcrições em papiro. Carson começa seu ensaio nos lembrando de que a poeta Safo era musicista: "sua poesia é lírica, isto é, foi composta para ser cantada acompanhada pela lira"5 (Carson 2003: ix). Menciona que há uma hydria no Museu Nacional de Antenas, do século V a.C., com uma representação de Safo lendo um papiro, embora não saibamos se ela era ou não letrada. Carson então esclarece que manipula o espaçamento "para restaurar alguma coisa de musicalidade ou sugerir movimento sintá- 
tico"6 (idem: xii) de Safo, o que seria perdido em sua mera transcrição em papiro ou em livro. Para exemplificá-lo, ela transcreve uma sentença citada em prosa por Crisipo em III a.C. - "nenhuma garota penso que olha para a luz do sol terá jamais uma sabedoria como esta"7 (idem: xi) - da seguinte forma:

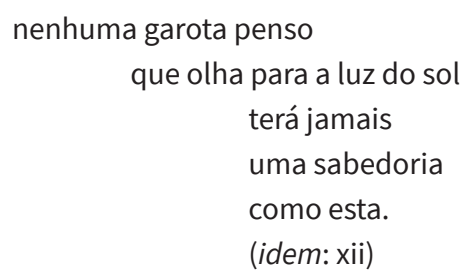

"Essa é uma licença tomada", explica Carson, "em deferência ao princípio que Walter Benjamin denomina 'a intenção em direção à linguagem' do original”8 (ibidem). Em seguida, cita um trecho do ensaio de Benjamin vertido para o inglês (cito aqui minha tradução da tradução de Carson):

\begin{abstract}
A tarefa do tradutor consiste em encontrar esse efeito pretendido na língua com a qual traduz, produzindo um eco do original[...] Diferentemente da obra literária, a tradução não se encontra no centro da floresta da linguagem, mas fora; convida sem entrar, e almeja aquele único ponto de onde um eco é capaz de dar, em sua própria língua, a reverberação da obra em língua estrangeira. ${ }^{9}$ (ibidem)
\end{abstract}

Eis aqui um dos princípios que gostaria de sublinhar na apropriação que Carson faz da teoria benjaminiana da tradução: traduzir significa, para ela, ouvir aquilo que fala no original, para fazê-lo ecoar. É essa política da escuta, implícita na ideia de "eco do original", que está na base da hipótese de que podemos aprender algo com as peças traduzidas. A tradução tem por tarefa também fazer ecoar o som reproduzido no original - um som que não pertence somente à língua de origem, mas que pode ser reproduzido enquanto se dizem outras coisas na língua de destino.

Isso que nos leva ao segundo texto que gostaria de comentar. Refiro-me à introdução de Carson a Antigonick, escrita em forma de carta-poema. Ali, a tradutora mimetiza o título de Walter Benjamin, "A tarefa do tradutor" (Die Aufgabe des Ubersetzers), que se torna "A tarefa de quem traduz Antígona" (The task of the translator of Antigone). ${ }^{10}$ Nessa introdução, Carson quer repensar uma tarefa mais específica: não somente a de quem traduz, mas mais precisamente a de quem traduz essa tragédia, dessa heroína, Antígona. Começa o texto se dirigindo a ela: "querida Antígona”. Já seus últimos versos, se despedem afirmando: "querida Antígona, / tomo como a tarefa da tradutora / nunca deixar que você perca os seus gritos"11 (Carson / Sófocles 2015: 6). Que são esses gritos? 
Para compreendê-lo, relembremos brevemente a tragédia de Antígona. Trata-se de uma das filhas de Édipo com sua mãe Jocasta. Do incesto nasceram também a irmã Ismênia e os irmãos Etéocles e Polinices. Antígona é herdeira, como seus irmãos, da maldição que atravessa a casa de Lábdaco (tendo em Édipo o seu ápice) e que sela o destino da cidade de Tebas. Ela sofrerá um acúmulo de catástrofes. Primeiro, após a descoberta do destino trágico de Édipo, testemunha o suicídio da mãe e o exílio do pai, que abandona Tebas e deixa um vácuo de poder. Verá então Etéocles e Polinices disputarem o trono em uma guerra sangrenta entre Tebas e Argos. Viverá para saber do assassínio de um pelo outro, simultaneamente. Depois, tomará ciência de que Creonte, seu tio e pai de seu prometido, assumiu tiranicamente o poder e proibiu o enterro de Polinices, por ser considerado traidor da cidade (ele lutara do lado de Argos), conferindo as honras funerárias apenas a Etéocles. Com um irmão honrado e o outro não, Antígona considerará que as leis do sangue e dos mortos não foram obedecidas. Tentará convencer Ismênia a ajudá- la a enterrar o corpo de Polinices - mas a irmã irá se recusar. Enterrará o irmão sozinha, e, por cometer esse "crime", será condenada à morte. Creonte ordenará que a enterrem viva. Antígona lamentará que não se casará com o prometido Hêmon, filho de Creonte. Hêmon se suicida com a morte de Antígona. Eurídice, mãe de Hêmon, se suicida após a morte do filho.

Em meio a essa ruína generalizada, Antígona se lamenta, muitas vezes, com gritos estranhos, ora semelhantes a uivos, ora semelhantes a um chilrear. O guarda explica a Creonte, por exemplo, que ela emite sons bizarros enquanto atira terra sobre o corpo do irmão, momentos antes de ser capturada. E é esse som que Anne Carson quer escutar aqui. O som que faz Antígona quando sua voz lutuosa tende ao sem sentido. Na tradução da poeta, lemos o seguinte quando o guarda (é ele quem está falando) a encontra:

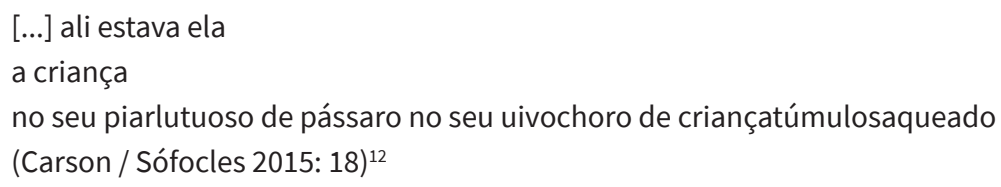

Mais tarde, será Tirésias, o adivinho, que ouvirá outro barulho estranho, dessa vez vindo dos pássaros, e é difícil não pressentir algo do grito sem sentido de Antígona no som que emitem. Não por acaso, Tirésias diz isso a Creonte logo após a condenação de Antígona. Na tradução de Carson:

você se equilibra sobre uma navalha eu ouço os pássaros eles estão bebarbarizados eles estão fazendo barulhos monstruosos (idem: 35$)^{13}$ 
A palavra que traduzo aqui como "bebarbarizados" é o neologismo correspondente de Carson, "bebarbarizmenized", para o grego "bebarbarōmenōi" ( $\beta \varepsilon \beta a \rho \beta a \rho \omega \mu \varepsilon ́ v \omega)$ de Sófocles, derivado de "barbaros" (ßápßapos). Esses vocábulos referem-se diretamente a uma língua estrangeira, principalmente no que ela tem de balbucio e de incompreensível para quem não a fala. Para os gregos, significava também a fala que se ouve fora da civilização, mais próxima, supostamente, dos animais. O procedimento de Carson para a tradução nessa cena da fala de Tirésias é o mesmo usado na cena do guarda quando avista Antígona: a confecção de neologismos para um som que ultrapassa o que se pode compreender. Ao mesmo tempo em que cria algo (pois não há estrangeirismos no original), restitui um "efeito" que "estava” lá: um êxodo para fora da civilização.

Um pequeno fragmento em outra obra mais recente de Carson nos ajuda a compreender esse êxodo. Em Norma Jeane Baker of Troy, a versão de Carson para a Helena de Eurípedes, entre os verbetes que a tradutora interpola à ação, encontra-se a seguinte entrada:

\author{
ßápßapos \\ "bárbaro, Outro"
}

[...] Bárbaros sempre vêm de algum lugar estranho, do outro lado da Terra de Ninguém ou do oceano ou da cerca. Eles são as outras espécies[...] Os gregos antigos deram o nome de barbaros a qualquer pessoa que não fosse provavelmente ou originalmente um grego. A palavra é pensada para replicar o som produzido por ovelhas: bar bar bar bar. ${ }^{14}$ (Carson 2019: 51)

Na tragédia grega, esses sons bárbaros são emitidos, muitas vezes, por figuras do sofrimento que se encontram na própria civilização. Quando a civilização se assemelha a um acúmulo de catástrofes, o lamento de Antígona e outras personagens se aproxima, para os ouvidos dos civilizados (que separam natureza e cultura, civilização e barbárie), dos animais, das ovelhas, dos pássaros, dos cachorros. Essas figuras são imagens do outro da civilização emergindo da própria civilização, quando ela se revela como agente de uma violência desenfreada e daquilo que não tem sentido.

O êxodo para fora da própria língua de origem, e do original, é o que Carson tenta escutar como tradutora. É a partir dessa escuta que ela acessa os arquivos do luto.

\title{
Os arquivos do luto
}

Na tragédia de Sófocles, quando Antígona é levada pelos guardas para ser enterrada viva como punição por haver enterrado o irmão, o coro de anciãos de Tebas compara a sua história com outras, como a de Dânae ou a dos filhos de Fineu, pela semelhança da situação de encarceramento e danação da própria heroína com o que encontramos nesses mitos, tendo como principal mote a inexorabilidade do destino. Quando Carson traduz esse trecho, insere no coro um comentário sobre a forma da tragédia. A partir de um 
procedimento de ironia formal, Carson faz o coro suspender a comparação para pensar sobre a sua própria função. Ao invés do acesso imediato às histórias que são comparadas à de Antígona, lemos:

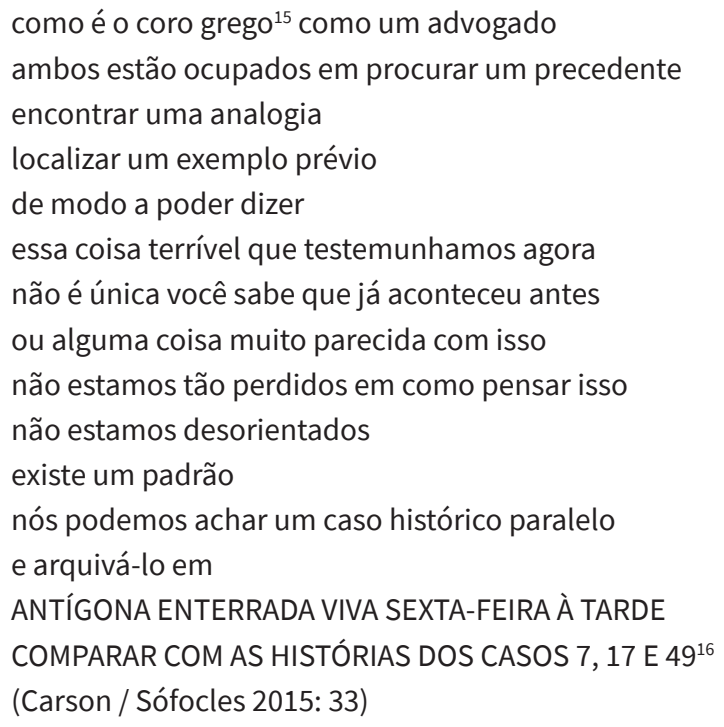

O coro como um advogado que procura outras formas de sofrimento equiparáveis, de maneira a buscar um padrão, um sentido comum a esses sofrimentos. Mas o gesto de Carson revela algo sobre a sua própria prática como tradutora. Não alude somente à função de justificação e de defesa jurídica do coro na tragédia antiga. Subentendido por oposição, esse comentário alude ao modo como a autora revira esses arquivos para investigar a singularidade de cada destino trágico. Retirar esses acontecimentos da compulsão à identidade que os classifica em um padrão. O coro diz, alguns versos adiante, que fazer comparações "não iria ajudar você / não me ajuda / é tarde de sexta-feira / e lá vai Antígona para ser enterrada viva / há / algum jeito / de dizer / que isso é normal / racional / perdoável / ou mesmo justo em alguma definição mais abrangente"? Ao que conclui com o comentário "não na verdade não"17 (ibidem).

A tradução em Carson aparece como performance para tornar estranho um episódio arquivado na tradição - e que se dissolveria na homogeneidade dos casos arquivados - a partir da escuta de sua singularidade. A tradução é a prática dessa escuta. Ela ecoa no vestígio, isto é, no texto traduzido.

Ora, Antígona é um caso exemplar aqui, pois pertence a uma casa arruinada, a dos descendentes de Lábdaco, rei de Tebas. O coro de Sófocles reflete sobre isso, quando a condenação de Antígona já bate à porta, nos versos 594-597. Na tradução de Trajano Vieira para o português, esses versos dizem o seguinte: 


\author{
Antigas adversidades dos falecidos \\ labdácias recaem \\ sobre adversidades. \\ Geração não poupa geração \\ (Vieira / Sófocles 2009: 58)
}

"Antigas" aí traduz o termo grego "arkhaios" (ảpxaĩos) cujo significado pode de fato ser "antigo" uma vez que deriva de "arkhé" ( $\alpha \rho x n ́)$, que tem, entre as suas possibilidades, o sentido de "origem", "início", "começo" (de onde também se derivariam os termos que se referem ao arcaico, ao arqueológico, ao acervo etc.). O mesmo trecho é traduzido por Mário da Gama Kury da seguinte maneira: "Vejo às antigas infelicidades / da casa dos labdácias juntarem-se / as novas desventuras dos defuntos, / e as gerações mais novas não resgatam / as gerações passadas" (Kury 1990: 228). Carson traduz esses versos usando a palavra "archive", arquivo: "arquivos do luto vejo caírem sobre essa casa / morte no nascimento nascimento na morte isso não tem fim"18 (Carson / Sófocles 2015: 23).

A tradução de arkhaios por archives ressalta a ambivalência que Carson quer atribuir a essa origem. Num primeiro sentido, trata-se de uma história antiga de destinos malogrados - Lábdaco, Laio, Édipo, Antígona. A ele, se soma um segundo sentido, que se liga ao comentário do coro sobre a sua função de advogado: o arquivo é um imenso banco de dados das catástrofes e dos sofrimentos que elas originaram. Ele em si é uma catástrofe e um sofrimento - homogeneizar e catalogar a história dos arruinados por graus de parentesco e semelhança, procurando nela algum sentido, equivale a perpetuar a catástrofe. Como não lembrar aqui do último ensaio de Walter Benjamin, seus fragmentos "Sobre o conceito de história", em que o filósofo denuncia os monumentos de cultura como monumentos da barbárie, (Benjamin 1987:225) demandando uma história a contrapelo que pudesse interromper o fluxo homogêneo e vazio da história dos vencedores (idem: 229)? O historiador exigido por Benjamin (que, aliás, volta a recorrer ao conceito de Aufgabe, tarefa, aqui - a tarefa do historiador materialista) aparece, de relance, na tradutora exigida por Anne Carson: "O perigo ameaça tanto a existência da tradição como os que a recebem. [...] Em cada época, é preciso arrancar a tradição ao conformismo, que quer apoderar-se dela" (idem: 224).

Seria preciso revisitar, então, esse arquivo, para bagunçar um pouco as coisas, escutando a singularidade daquilo que não produz sentido, daquilo que é sem sentido, que resiste a ele. Como o grito de Antígona. Uma vez que o luto é um trabalho emocional que realizamos diante de uma perda irreparável, esse sem sentido do sentido designa aquilo que foi destruído na arkhé, na origem. No original.

A mesma questão se interpõe na tradução que Carson faz da Elektra de Sófocles. "Às vezes as pessoas dizem de Elektra que seu luto [mourning] é excessivo. Ela não discordaria"19 (Carson 2010: 77). "Não posso não estar de luto [grieve]"20 (idem: 78), nos 
diz a heroína no verso 181, citado por Carson na sua introdução à Elektra. "Ela não tem escolha, porque ela não tem outro eu que não esse que se enluta [mourns]"21 (idem: 77). Então o que resta a essa personagem que só pode se enlutar? "Fazer barulho", 22 é a resposta de Carson (idem: 79). E arremata: "ela não é nenhuma Antígona [...] mas sempre vale a pena escutá-la"23 (idem: 80 ). Nesse contexto, o barulho que faz Elektra e que produz o sem sentido se manifesta no significante do original. Ao invés de traduzir a palavra

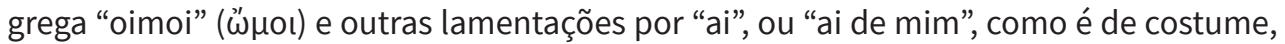
Carson mantém a transliteração do significante original - que agora, em novo contexto, é meramente um ruído: "OIMOI TALAINA. / Agora eu sofro [grief] o bastante para gritar OIMOI-" (idem: 128$)^{24}$

\section{As lições patéticas}

Se a tradução tenta restituir o sem sentido do sentido do original na língua traduzida, o que podemos esperar da leitura do sem sentido dos arquivos do luto? A julgar pelo título de um dos volumes de tradução de Anne Carson, Lições do Luto, algum aprendizado.

Trata-se aqui da antiga questão do potencial pedagógico da mimesis? Essa questão é apresentada por Aristóteles na Poética, em que define a mimesis como fonte, a um só tempo, de aprendizagem e prazer (o que se converterá, com o tempo, na exigência que os tratadistas das belas artes farão aos artistas para que instruam e agradem). "De fato, a ação de mimetizar se constitui nos homens desde a infância”, nos explica Aristóteles, ao definir o ser humano como o mais mimético dos animais. Os humanos "recorrem à mimese para efetuar suas primeiras formas de aprendizagem, e todos se comprazem com as mimesis realizadas" (Aristóteles 2017: 57). E Anne Carson está atenta a essa tese, que segue de perto, inclusive num poema-ensaio que intitulou como "Ensaio sobre o que mais penso", em que cita a teoria da mimesis de Aristóteles a partir de um comentário não à Poética, mas à Retórica e à teoria da metáfora:

\footnotetext{
Muitas pessoas inclusive Aristóteles consideram o erro

um evento mental interessante e valioso.

Na sua discussão sobre a metáfora na Retórica

Aristóteles diz que há 3 tipos de palavras.

Estranhas, comuns e metafóricas.
}

As palavras estranhas simplesmente nos causam estranhamento;

palavras comuns expressam o que nós já sabemos;

é a partir da metáfora que conseguimos chegar a algo novo \& vigoroso.

(Retórica, 1410b, 10-13) 
Em que consiste o vigor da metáfora?

Aristóteles diz que a metáfora faz com que a mente se submeta a experiências

ao cometer um erro. ${ }^{25}$

[...]

\section{[...] Imitação (mimesis em grego)}

é o termo coletivo de Aristóteles para os verdadeiros erros da poesia.

(Carson 2016)

Admitamos, a princípio, que haja na prática da tradução de Carson, e na ideia de que pode haver algum aprendizado com o luto encenado nas tragédias, a concepção aristotélica de que as ações e os produtos da mimesis nos ensinam alguma coisa. No seu ensaio introdutório às Lições do Luto, Carson se pergunta: "por que a tragédia existe?" Ao que responde: "porque você está cheio de raiva. Por que você está cheio de raiva? Porque você está cheio de luto [grief] [...] Luto e raiva - você precisa conter isso, colocar essa coisa numa moldura onde ela possa se desenrolar"26 (Carson 2006e: 7). Essa moldura seria a mimesis - e no caso dos afetos luto e raiva, a forma da mimesis adequada é a tragédia. Mais uma vez, Carson segue de alguma maneira a ideia aristotélica de tragédia, e alude à teoria da catarse: "há uma teoria que diz que assistir a histórias insuportáveis sobre outras pessoas perdidas em luto e raiva seria bom pra você"27 (ibidem).

Mas há boas razões também para contestar a identidade entre a teoria da tragédia em Aristóteles e em Carson. Em primeiro lugar, porque para a poeta, a mimesis em Eurípedes, que é o dramaturgo traduzido por ela em Lições do Luto, não causa nenhum prazer ("Por que Eurípedes é tão desprazeroso? Certamente é. Certamente eu não sou a única pessoa que pensa isso"28) (Carson 2006b: 89). Em segundo lugar, porque justamente Eurípedes, o "mais trágico" dos poetas gregos segundo Aristóteles, como afirma Carson, frustra sistematicamente os elementos exigidos pela tragédia: "a organização básica da ação" (com início, meio e fim), "um herói ou heroína reconhecível" e "uma questão moral evidente" (idem: 90-91). Para Carson, Eurípedes é o mais trágico dos poetas gregos e se empenha, ao mesmo tempo, em subverter todas essas regras de composição, parte delas presente na Poética de Aristóteles, inclusive. Se a teoria da tragédia não coincide em Aristóteles e em Carson, e se não corresponde meramente à possibilidade de aprendizado pela mimesis, a que se refere essa pedagogia aludida no título do volume Lições do Luto?

Vejamos essa questão não singularmente, em cada um dos textos dessa coletânea, mas num sobrevoo de sua arquitetura.

Lições do Luto traduz quatro peças de Eurípedes, com uma introdução para cada uma: Héracles, Hécuba, Hipólito e Alceste. A elas, Carson acrescenta dois paratextos que já mencionei: um epílogo, "assinado" por Eurípedes, e um escrito introdutório, sobre a forma da tragédia. Essa introdução apresenta também Eurípedes como um poeta da segunda me- 
tade do século quinto a.C. e que, portanto, testemunhou a terrível Guerra do Peloponeso, entre Atenas e Esparta. Um evento histórico brutal que ultrapassou o período de sua vida e que deu fim à "Grécia clássica”. "A Guerra do Peloponeso começou em 431 a.C. e durou até depois da morte de Eurípedes. Trouxe corrupção, distorção, decadência e desespero à sociedade e aos corações dos indivíduos"29 (Carson 2006e: 8). Carson nos apresenta Eurípedes como alguém que "usou os mitos antigos como lentes" (ibidem), a sua técnica dramatúrgica propicia "uma espécie de aprendizado que está sempre em ponto de ebulição"30 (ibidem).

Os ensaios de Carson que introduzem cada uma das quatro peças apresentam também pequenas lições que acompanham esses mitos. Por ora, não será necessário retomar a descrição detalhada de todos eles; bastará extrair dos prefácios de Carson quais lições se originam do sofrimento nessas tragédias.

Primeiro, Héracles. A poeta descreve Héracles como um herói "brutalizado e brutalizante", tomado pelas Fúrias e forçado a cometer um assassínio terrível de sua própria família, que o deixará no chão quando retornar a si (Carson 2006b). Até esse episódio de sua vida, segundo Carson, Héracles é um herói solitário; mas no final da peça, que mostra o herói sendo reerguido pelo amigo Teseu, apresenta-se "uma nova postura heracleana", ${ }^{31}$ ao mesmo tempo que o coro, composto por homens velhos e quase sem forças, encarna esse mesmo ideal de "heroísmo colaborativo"32 (idem: 16). Apoiam-se uns nos outros, os heróis de um lado, os velhos de outro. Héracles se desilude com os deuses e decide não acreditar mais neles - o que significa também não acreditar na história de sua própria vida, já que é narrado no mito como um semideus.

(Isso acontece na tragédia que leva o seu nome. Mas ele retorna também em Alceste, e ali sua função é outra: o prefácio de Carson (2006a) mostra um Héracles fanfarrão que chega à casa de Admeto e o ajuda a enganar a morte, quebrando as suas regras. Mas Anne Carson acaba por admitir que entre as quatro peças comentadas, Alceste é aquela sobre a qual a poeta diz menos: "não porque haja menos nessa peça, mas porque ela parece ter uma velocidade e um brilho que evaporam com a exegese") ${ }^{33}$ (idem: 249).

No prefácio a Hécuba, Carson nos fala da rainha de Tróia como o signo da espoliação mais absoluta: sua cidade se arruína, seu marido e filhos são destruídos, e sua filha Polixena é levada para aplacar a demanda do fantasma de Aquiles. Quando o último fiIho, Polidoro, é assassinado de maneira traiçoeira, ela se levanta de sua prostração "e se recompõe uma última vez para a ação", dessa vez "jubilosa, viciosa, uma coisa chocante de se ver"34 (2006b: 90). O desejo de vingança se converte em ânimo, devolvendo alma à heroína, ao mesmo tempo em que a empurra para fora da civilização com o cumprimento da profecia de que se veria metamorfoseada em cachorro. O sofrimento de Hécuba foi tão grande, nos diz Carson, que "não há lugar algum ao qual ela possa ir, a não ser para fora da espécie"35 (ibidem).

Sobre Hipólito, Carson nos diz que Afrodite aparece como "pivô" da queda de todos: o feitiço da deusa do amor sofre Fedra, para que desejasse o enteado Hipólito, age com 
um "efeito dominó sobre os outros personagens"36 (Carson 2006d: 168). Os efeitos? 0 suicídio de Fedra, com uma carta sua ao marido Teseu mentindo sobre Hipólito; o exílio de Hipólito, e um acidente mortífero que choca sua carruagem contra as pedras; a tristeza infinita de Teseu. A motivação para o plano de Afrodite? Hipólito é apresentado como alguém que recusa o amor, reivindicando pureza a partir de seu culto a Ártemis e odiando a união com mulheres (odiando mulheres, inclusive). Afrodite decide se vingar, uma vez que ninguém recusa o amor impunemente. Mas seria difícil compreender Afrodite como causa, efetivamente, da queda de todos, pois "cada qual escolhe e comete ações que colaboram com o plano divino e destroem outros seres humanos"37 (ibidem). De um lado, temos a ação da deusa, que coloca as paixões humanas numa combinação determinada e explosiva; por outro, o livre-arbítrio. Em outras palavras, surge a questão de se a tragédia que se abate sobre os personagens é culpa do destino ou de suas próprias ações. Carson traduz o dilema usando o ovo como metáfora:

Uma grande questão do livre arbítrio e do determinismo aparecem. Eurípedes parece inclinado a nos conduzir ao centro dessa questão e nos deixar ali. Isso me faz pensar num ovo cozido. Corte-o ao meio. você verá um desenho requintado - o círculo amarelo está perfeitamente suspenso no molde oval branco. As duas figuras estão separadas e são diferentes, e mesmo assim constroem uma forma. Elas não se contradizem ou cancelam, elas interexistem. Você pode dizer que alguma delas é mais determinante? O círculo como um oval distorcido? O oval como um círculo imperfeito? Em vez disso, cada uma segue a outra num sistema perfeito chamado ovo. (ibidem) ${ }^{38}$

O que aprendemos com esses paratextos de Carson, anexados às traduções dessas tragédias? Ou: o que esses textos inventariam como possibilidade pedagógica nesses dramas? As opções pela desilusão e pelo abandono da própria história (e da vida autossuficiente) como possibilidade de recomeço de uma vida (Héracles e Alceste). A disponibilidade do desejo de vingança como ânimo possível a quem foi objeto da espoliação total (Hécuba). A contemplação do sistema que configura um tenso equilíbrio, ou desequilíbrio, entre destino e arbítrio humano (Hipólito). Não são lições que transmitem exatamente um sentido - mais vale dizer que elas apresentam possibilidades de existência. Colocam à nossa disposição determinadas qualidades ou ethos.

E em todos esses casos, Carson vasculha os arquivos do luto em busca de lições patéticas. O pathos que aí se enuncia já não corresponde a qualquer virtude moral, mas àquilo que se sofre e se vive. A investigação nos arquivos do luto, por meio da tradução, implica uma educação sentimental. Não no sentido de que ela refina os sentimentos, mas no de que coloca à disposição dos que escutam a ruína um conjunto de hipóteses sobre as paixões e os sofrimentos. O sofrimento, aqui, ensina porque se conecta com os desejos, com as forças anímicas. O pathos reinforma e reconfigura o ethos. Nesse sentido, os arquivos do luto se transmutam: se o perigo desse arquivo é, como vimos, em Antigonick, 
a homogeneização e perpetuação das catástrofes, a sua salvação está nas ações que o transformam por elaboração. A tradução é uma dessas ações. A ação - o drama, como sabemos, em sua origem etimológica, é ação - ensina.

\section{NOTAS}

* Rafael Zacca é professor agregado no Departamento de Filosofia da PUC-Rio e professor convidado na especialização em Filosofia contemporânea na mesma instituição. Realiza um estágio de Pós-Doutorado na Unifesp, onde desenvolve uma pesquisa acerca da prática da tradução em Anne Carson. Em sua tese de doutorado, defendida na PUC-Rio em 2019, se dedicou a investigar uma teoria do poema em Walter Benjamin. É crítico e publicou Formas nômades (Margem da palavra, 2021) e colabora com o jornal Rascunho e com a revista Pessoa. Também é poeta, e publicou, entre outros, O menor amor do mundo (7Letras, 2020). Ministra oficinas de criação literária na editora 7Letras.

${ }^{1}$ Todos os trechos de Anne Carson citados em português com referência bibliográfica em inglês são traduções minhas. No original: "not exactly god. ghost, spirit, angel, principle or element - / There is no term for it in English. / In Greek they say daimon - / can we just use that?"

${ }^{2}$ Não parece haver, em Carson, uma distinção muito precisa, do ponto de vista conceitual, entre as palavras grief e mourning, pelo menos nos textos que investigamos aqui. Elas aparecem indiscriminadamente em suas traduções e em seus prefácios e ensaios. Normalmente poderíamos traduzi-las por "sofrimento" e "luto" respectivamente: mas nos textos de Carson, elas aparecem quase como sinônimos, ou algo muito próximo disso. Por fim, esclareço que tanto grief quanto mourning carregam, aqui, os sentidos que atribuímos a diferentes palavras, e têm como possibilidades semânticas tristeza, sofrimento, aflição, luto, agonia, remorso, ressentimento, pesar, amargura e dor.

${ }^{3}$ Irei recorrer aqui sempre à tradução de Susana Kampf Lages para o volume Escritos sobre mito e linguagem. Chamo a atenção do leitor para um volume, no entanto, editado em 2008 pela Fale / UFMG, que reúne quatro traduções para Die Aufgabe des Übersetzers. Foi intitulado A tarefa do tradutor de Walter Benjamin: quatro traduções para o português, e inclui o original em alemão, a tradução de Lages, outras três e um índice de obras em português nas quais trechos do ensaio aparecem traduzidos por outros comentadores importantes do filósofo, como Haroldo de Campos, Jeanne Marie-Gagnebin, Marcio Seligmman-Silva etc.

${ }^{4}$ Sobre o conceito de Aufgabe, tarefa, em Walter Benjamin, e suas consequências para repensar o papel da tradução, da reescrita e da crítica de obras de arte, conferir o capítulo "Tarefa: Criticabilidade | Traduzibilidade | Refazibilidade" em As flores da poesia na terra do saber: uma teoria do poema em Walter Benjamin (Fernandes 2019: 66-71). 
5 "Her poetry is lyric, that is, composed to be sung to the lyre."

6 "to restore a hint of musicality or suggest syntactic motion".

${ }^{7}$ Optei por traduzir a tradução de Carson. Nela, lemos a sentença: "Not one girl I think who looks on the light of the sun will ever have wisdom like this."

8 "This is a license undertaken in deference to a principle that Walter Benjamin calls 'the intention toward language' of the original."

${ }^{9} \mathrm{Na}$ tradução brasileira feita por Susana Kampff Lages, lemos:

Essa tarefa [do tradutor] consiste em encontrar na língua para a qual se traduz a intenção a partir da qual o eco do original é nela despertado. Aqui está um traço que distingue tradução e obra poética, pois a intenção desta nunca se dirige à língua enquanto tal, à sua totalidade, mas única e imediatamente a determinados contextos de teor de linguagem. Mas a tradução não se vê como a obra literária, mergulhada, por assim dizer, no interior da mata da linguagem, mas vê-se fora dela, diante dela, e, sem penetrá-la, chama o original para que adentre aquele único lugar, no qual, a cada vez, o eco é capaz de reproduzir na sua própria língua a ressonância de uma obra da língua estrangeira. (Benjamin 2011: 112)

${ }^{10}$ Trata-se de um texto que Anne Carson lia, quando da primeira publicação e das primeiras leituras públicas de Antigonick, antes das performances. Na segunda edição, em paperback, o texto foi incorporado como introdução à tradução. Há três traduções para o português na revista Escamandro, disponíveis em https://escamandro.com/2017/01/13/3-traducoes-para-o-task-of-the-translator-da-antigonick-de-anne-carson/ , último acesso em 02/07/2021.

11 "dear Antigone / I take it as the task of the translator / to forbid that you should ever lose your screams".

12 "...there she was / the child / in her birdgrief the bird in her childreftgravecry howling".

13 "you're standing on a razor / I hear the birds they're bebarbarizmenized they are / making monster sounds".

14 “'barbarian, Other'[...] Barbarians always come from somewhere uncanny, on the far side of No Man's Land or an ocean or the fence. They are another species[...] Ancient Greeks gave the name barbaros to anyone not provably or originally a Greek. The word is thought to replicate the sound made by sheep: bar bar bar bar."

${ }^{15}$ Carson opta por não pontuar as interrogativas, e nesta tradução decidi manter a ausência de pontuação da autora.

16 "how is a Greek chorus like a lawyer / they're both in the business of searching for a precedent / finding an analogy / locating a prior example / so as to be able to say / this terrible thing we're witnessing now is / not unique you know it happened before / or something much like it / we're not at a loss how to think about this / we're not without guidance / there is a pattern / we can find an historically parallel case / and file it away under / ANTIGONE BURIED ALIVE FRIDAY AFTERNOON / COMPARE CASE HISTORIES 7, 17 AND 49”

17 “it wouldn't help you / it doesn't help me / it's Friday afternoon / there goes Antigone to be buried alive / is there / any way / we can say / this is normal / rational / forgivable / or even in the widest definition just / no not really"

18 "archives of grief I see falling upon this house / death on birth birth on death there is no end to it"

19 "People sometimes say of Elektra that her mourning is excessive. She would not disagree."

20 "I cannot not grieve."

21 "She has no choice, beacause she has no Other self than the one that mourns."

22 "Make noise." 
23 "She is no Antigone[...] But she is always worth listening to."

24 "OIMOI TALAINA. / Now I have grief enough to cry out OIMOI-"

${ }^{25}$ No original, o texto de Carson (2001: 37) diz: "Aristotle says that metaphor causes the mind to experience itself / in the act of making a mistake." João Moita traduziu o mesmo trecho da seguinte forma: "Aristóteles diz que a metáfora torna a mente consciente de si mesma / no momento de cometer um erro." Essa duplicidade de leituras da tradução coloca parte do problema tal como ele aparece na Retórica de Aristóteles e no texto de Carson. Essas opções aludem ao fato de que para Aristóteles (ou ao menos o Aristóteles de Carson) a metáfora faz com que a mente "se submeta a experiências" (como se experimentasse a si mesma na imaginação) ou se torne "consciente de si mesma", ao perceber-se aprendendo depois de cometer um erro lógico. As opções de tradução aludem, assim, com Carson, ao capítulo da Retórica sobre a metáfora em que o filósofo afirma que essa figura de linguagem pode "proporcionar aprendizagem" ao fazer com que "o objeto salte para 'diante dos olhos"” (Aristóteles 2005: 266)

26 "Why does tragedy exist? Because you are full of rage. Why are you full of rage? Because you are full of grief [...] Grief and rage - you need to contain that, to put a frame around it, where It can play itself out".

27 "There is a theory that watching unbearable stories about other people lost in grief and rage is good for you".

28 "Why is Euripides so unpleasant? Certainly he is. Certainly I am not the only person who thinks so."

29 "The Peloponnesian War began 431 BC and lasted beyond Euripides' death. It brought corruption, distortion, decay and despair to society and to individual hearts"

30 "he used ancient myth as a lens [...] There is in Euripides some kind of learning that is always at the boiling point."

31 "a new Heraklean posture"

32 "collaborative heroism"

33 "Not because there is less in this play but because the surface has a speed and shine that evaporate with exegesis"

34 "assembles herself one last time to action. She is jubilant, she is vicious, she is a shocking thing to see"

35 "there is nowhere for her to go but out of species"

36 "has a domino effect on the other characters"

37 "each chooses and commits actions that collaborate with the divine plan and destroy another human"

38 "A large question of free will and determinism comes to mind. Euripides seems inclined to lead us into the middle of this question and leaves us there. It makes me think of a hardboiled egg. Cut it open, you see an exquisite design - the yellow circle perfectly suspended within the white oval. The two shapes are disjunct and dissimilar yet construct one form. They do not contradict or cancel out, they interexist. Can you say one is prior? Circle as distorted oval? Oval as imperfect circle? Rather they each follow the other in a perfect system called egg." 


\section{BIBLIOGRAFIA}

Aristóteles (2017), Poética. Tradução de Paulo Pinheiro, São Paulo, editora 34.

-- (2005), Retórica. Tradução de Manuel Alexandre Júnior, Paulo Farmhouse Alberto e Abel do Nascimento Pena, Lisboa, Imprensa Nacional - Casa da Moeda.

Benjamin, Walter (2011), "A tarefa do tradutor", in Escritos sobre mito e linguagem, tradução de Susana Kampff Lages, São Paulo, Duas Cidades / Ed. 34.

-- (2008), A tarefa do tradutor de Walter Benjamin: quatro traduções para o português, organização de Lucia Castello Branco, Belo Horizonte, Fale / UFMG.

-- (1987), Obras reunidas volume I, Magia e técnica, arte e política, tradução de Sergio Paulo Rouanet, São Paulo, Brasiliense.

Buck-Morss, Susan (2018), O presente do passado, tradução de Ana Luiza Andrade e Adriana Varandas, Desterro (Florianópolis), Cultura e Barbárie.

Campos, Haroldo de (2015), Transcriação, São Paulo, Perspectiva.

Carson, Anne (2010), An Oresteia: Agamemnon by Aiskhylos; Elektra by Sophokles; Orestes by Euripides, New York, Faber and Faber.

-- (2016), "Ensaio sobre o que mais penso", tradução de Fernanda Drummond, Revista A! <https://revista-a.org/2016/02/19/ensaio-sobre-o-que-mais-penso-de-anne-carson/> (último acesso em 05/08/2021).

-- (2013), "Ensaio sobre aquilo que mais penso", tradução de João Moita, Enfermaria 6 < http://www.enfermaria6.com/blog/2013/12/2/ensaio-sobre-aquilo-em-que-maispenso-anne-carson > (último acesso em 14/11/2021)

-- (2003), "Introduction" in Sappho, If Not, Winter: fragments of Sappho, tradução de Anne Carson, Nova York, Vintage Books, ix-xiii.

-- (2020), "Eu queria ser dois cachorros para brincar comigo mesma (nota da tradutora sobre bakkhai de eurípedes)", tradução de Inês Cardoso Martins Moreira, Sala400, vol. 1, n. 1. Disponível em < https://0560cf2e-04ed-4e73-8668-b53095f555d6.filesusr.com/ugd/13f b17_7a3439bee4634d548c75a8d47cf0dbe0.pdf > Último acesso 30/07/2020.

-- (2001), Men in the off hours, New York, Vintage / Random House.

-- (2019), Norma Jeane Baker of Troy: a version of Euripides's Helen, New York, New Directions.

-- (2006a), "Preface to Alkestis", in Carson, Anne / Euripides, Grief Lessons, New York, New York Review of Books, 247-249.

-- (2006b), "Preface to Hekabe", in Carson, Anne / Euripides, Grief Lessons, New York, New York Review of Books, 89-97.

-- (2006c), "Preface to Herakles", in Carson, Anne / Euripides, Grief Lessons, New York, New York Review of Books, 13-17.

-- (2006d), “Preface to Hippolytos”, in Carson, Anne / Euripides, Grief Lessons, New York, New York Review of Books, 163-169.

-- (2006e), “Tragedy: A curious Art Form”, in Carson, Anne / Euripides, Grief Lessons, New York, New York Review of Books, 7-9. 
-- (2017), "Três traduções para o 'task of the translator' da Antigonick de Anne Carson", Escamandro < https://escamandro.com/2017/01/13/3-traducoes-para-o-task-of-thetranslator-da-antigonick-de-anne-carson/ > (último acesso em 02/07/2021)

-- (2006f), "Why I Wrote Two Plays About Phaidra. By Euripides”, in Carson, Anne / Euripides, Grief Lessons, New York, New York Review of Books, 309-312.

Carson, Anne / Eurípedes (2015), Bakkhai. London, Oberon Books.

--(2006), Grief Lessons, New York, New York Review of Books.

Carson, Anne / Sófocles (2015), Antigonick, New York, New Directions.

Fernandes, Rafael Zacca (2019), As flores da poesia na terra do saber: uma teoria do poema em Walter Benjamin, Tese (Tese em Filosofia) - Departamento de Filosofia, Pontifícia Universidade Católica do Rio de Janeiro, Rio de Janeiro.

Gonçalves, Rodrigo Tadeu / Nascimento, Julia (2019), "A tradutora e o diálogo intermidiático em Antigonick de Anne Carson", Classica, v. 32, n. 1, 79-91.

Hjorth, Ben, (2014) 'We're Standing in/the Nick of Time', Performance Research, 19:3, 135139.

Lages, Susana Kampff (2007), Walter Benjamin: Tradução e Melancolia, São Paulo, EdUSP.

Cardoso Martins Moreira, Inês (2015), "Antigonick e o espaço textual da performance", in Ruiz, Giselle (org), Articulações. Ensaios sobre corpo e performance, prefácio de Angela Leite Lopes, Rio de Janeiro, 7letras, 117-132.

-- (2019), "Tradução e comentário: Anne Carson e seus espelhamentos ensaísticos às traduções de tragédias gregas”, Urdimento, Florianópolis, v.2, n.35, 249-262.

Silverblank, Hannah (2014), "Spectral presences and absences in Anne Carson's Antigonick" Logeion: Periodiko gia to Archaio Theatro, Issue 4, 343-363.

Sófocles (1990), A Trilogia Tebana, tradução de Mário da Gama Kury, Rio de Janeiro, Zahar. Vieira, Trajano / Sófocles (2009), Antígone de Sófocles, tradução de Trajano Vieira, São Paulo, Perspectiva. 